\title{
EFFECT OF PIX (MEPIQUAT CHLORIDE) ON THE SALINITY RESISTANCE OF NEW CULTIVARS OF COTTON (GOSSYPIUM HIRSUTUM L.) IN THE SEEDLING STAGE
}

\author{
JAFARI, M. ${ }^{1}$-SAADATMAND, S. ${ }^{1 *}$-ZANGI, M. R. ${ }^{2}$ - IRANBAKHSH, A. R. ${ }^{1}$ \\ ${ }^{1}$ Department of Biology, Science and Research Branch, Islamic Azad University, Tehran, Iran \\ ${ }^{2}$ Cotton Research Institute of Iran, Agricultural Research, Education and Extension Organization \\ (AREEO), Gorgan, Iran \\ *Corresponding author \\ e-mail: s_saadatmand@yahoo.com; phone: +98-912-211-5836 \\ (Received $9^{\text {th }}$ Feb 2018; accepted $12^{\text {th }}$ Jun 2018)
}

\begin{abstract}
In modern agriculture, mepiquat chloride (pix) as a synthetic growth regulator, is considered as an important management tool for reducing stress damage in Cotton seed. In the present study, the effects of the growth regulator, pix were investigated on the physiological and biochemical characteristics in new cultivars of cotton in response to salinity stress in Golestan province, Iran. The experiment was carried out in a completely randomized design enriched with $10 \mathrm{gr}$. $\mathrm{L}^{-1}$ Pix and $15 \mathrm{ds} \cdot \mathrm{m}^{-1}$ salt (sodium chloride) in Petri dish with three cultivars (Latif, Kashmar and Sahel). The physiological and biochemical parameters of seedlings were measured after 4 days. The use of Pix in saline conditions resulted in a significant increase in germination percentage, radicle length, dry and fresh weights, phenolic compounds, as well as proline and glycine betaine content in the Latif and Kashmar cultivars $(\mathrm{p} \leq 0.05)$. The amount of $\mathrm{Na}^{+}$ion absorption was lower in Kashmar and Latif cultivars compared with the Sahel cultivar while the amount of $\mathrm{K}^{+}$and $\mathrm{Ca}^{2+}$ ions absorption was increased in the two mentioned cultivars compared to the Sahel cultivar. This study showed that the effects of stress were reduced after treating the seeds with Pix, especially in the Kashmar and Latif cultivars during the seedling stage.
\end{abstract}

Keywords: salt stress, mepiquat chloride, synthetic growth regulator, enzyme activity, ion accumulation, osmotic regulator, Malvaceae

\section{Introduction}

Cotton (Gossypium spp.) is a flowering plant which belongs to the Malvaceae family. Today, it has gained importance both economically and commercially with regard to the production of fibers, raw material for textiles, the oil industry, food (Ozarslan, 2002) and various other materials for consumption. For a long time, salinity has been one of the major environmental problems faced by humankind (Jaleel et al., 2009) and is the basic limiting factor for production in arid and semi-arid inlands (Munns et al., 2002; Ashraf and Foolad, 2005). Like many areas of the world, Iran has a hot and dry climate and more than half of its cultivation lands has been transformed into saline and sodic soils (Jamali et al., 2015). Salinity stress affects the physiological and bio-chemical features of the plant and disrupting the osmotic balance (Kook et al., 2009) can lead to severely decreased plant growth and reduced amount of production (Koca et al., 2007).

Salinity stress and increasing $\mathrm{Na}^{+}$concentration cause a decrease in essential absorption including $\mathrm{K}^{+}$and calcium, and a reduction of enzyme activity and membrane structure (Demir Kaya et al., 2006; Netondo et al., 2004). An irreparable damage is caused by the plant through the production of reactive oxygen species (ROS) (Koca et al., 2007). Also, plants in saline areas are faced with water deficit in addition to the salinity stress. This affects plant metabolic reactions such as photosynthesis, respiration, and 
protein synthesis (Pal et al., 2004; Meloni et al., 2003). The effect of salinity is different in different periods of plant growth. Germination is the most critical stage of plant growth (Khan et al., 2002; Khan and Panda, 2008) including cotton (Weiping et al., 2009; Mer, 2000; Prado, 2000) so that germination can be prevented by increasing salinity (Sosa et al., 2005; McDonald, 2000; Godfery et al., 2004).

Each plant with more resistance can have a better growth during the later stages (Gulzar, 2001). The investigation showed that an increase in salinity caused a decrease in plant height, leaf surface, fresh and dry weight, as well as radicle and plumule length in the studied cultivars of cotton (Saranga et al., 2004; Noor et al., 2001). Even in susceptible (Sahel) and resistant (Siokra) cultivars of cotton, salinity also causes shortening in radicle and plumule length (Rezaei et al., 2005). An important effect of stress in plants is the overproduction of reactive oxygen species (ROS) in chloroplasts and mitochondria (Mittler, 2002; Masood et al., 2006).

The accumulation of secondary metabolites is one of the possible responses of plants to the changes in osmotic potential of the environment (Hasegawa et al., 2000). Plants accumulate compatible solution such as proline (Mansour et al., 2005a) and glycine betaine in the cell osmotic regulation (Rhodes and Hanson, 1993) to counteract the harmful effects of salt.

Glycine betaine is increased in plant as consistent and effective osmolytes under stressful conditions (Ashraf and Foolad, 2007), particularly under salinity stress (McNell et al., 2001). Increasing glycine betaine has been observed in response to salinity stress in spinach, cabbage, tomato, potato, Rice and sorghum (Yang et al., 2003). Also, increase in water salinity resulted in an increase in glycine betaine in two cotton cultivars (AriaAnubam and LRA - 5166) (Desingh and Kanagaraj, 2007). Proline is the amino acid that is accumulated under salinity stress as active osmotic regulator; it is widely used in higher plants (Abraham et al., 2003) and causes membrane stability and affects the membrane process.

Another effect of salinity stress on plants is the disruption of important nutrient balance including $\mathrm{K}^{+}$and $\mathrm{Ca}^{2+}$ (Renault, 2005). $\mathrm{K}^{+}$is an essential cytoplasmic element and is considered to be an important element in saline conditions as a result of its role in regulating osmosis and the competition effect. Also, several reports have emphasized the beneficial effects of $\mathrm{Ca}^{2+}$ in reducing the effects of salinity and in most cases these effects are related to restoring the plasma membrane, health maintenance and cohesion in roots and shoots (Nedjimi and Daoud, 2009; Kaya et al., 2002; Tuna et al., 2007). Various methods are used to reduce salinity in cotton. These include the use of growth regulators, selection and the cultivation of resistant genotypes. Pix as a synthetic growth regulator in Cotton seed is considered as an important management tool for reducing stress damage in modern agriculture (Jost et al., 2006; Niakan et al., 2012). Pix with the common name, mepiquat chloride, is composed of $4.2 \% \mathrm{~N}$, N-dimethylpiperidinium chloride and a multicomponent composition of Ammonia (it inhibits the synthesis of Gibberellic acid) (Stewart, 2005). The colonization of seeds with Pix before planting is an appropriate method of reducing salinity which can increase the length of roots with changes in seed physiology and impressing cell wall in the early stages of germination. Studies have shown that a significantly higher seed germination was observed in seeds treated with Pix compared to the control (Niakan et al., 2012).

It has been found that plants primed with Pix are shorter, denser and darker than plants that are not stained with it (Stewart, 2005). The use of Pix leads to the absorption of more phosphorus and nitrogen (Oosterhuis and Robertson, 2000) and the concentration of 
magnesium, phosphorus, and nitrogen in the root is more compared to the control group (Osterhuis and Robertson, 2000; Zhang et al., 2001). The literature review revealed that the use of Pix at high concentrations of salt resulted in improved germination and an increase in physiological characteristics such as root length, fresh and dry weight and increased biochemical properties such as catalase activity and the amount of phenol (Alishah et al., 2012).

The objective of this study was to investigate the effect of Pix (mepiquat chloride) on the salinity resistance of the new cultivars of cotton (Gossypium hirsutum L.) in Gorgan area, Golestan province, Iran.

\section{Materials and methods}

\section{Plant material}

Delinted cottonseed (Gossypium hirsutum L.) from three cultivars (Kashmir, Latif and Sahel) was prepared in the Cotton Research Center of Iran, Gorgan city, Golestan Province, (36 $56^{\circ}$ North and $54^{\circ} 26^{\prime}$ East) which is located in the North East of Iran.

The experimental design was completely randomized with priming Pix (10\%) and salt $\left(15 \mathrm{ds} . \mathrm{m}^{-1}\right)$ in the Petri dish with three mentioned cultivars (Latif, Kashmar and Sahel) at the germination stage. In addition, four treatments (Pix, salinity, Pix and salinity and control) were studied with four replications from three cultivars in 48 Petri dishes.

Sahel cultivar was considered as control (grown in northern areas and most areas of Iran) and two new cultivars of Latif and Kashmar were used as treatments that were developed and recorded in the year 2015 in the Cotton Research Institute of Iran through crop breeding. Cotton seeds priming was performed with $10 \mathrm{gr} . \mathrm{L}^{-1}$ (gram/liter) Pix for $5 \mathrm{~h}$ at $25{ }^{\circ} \mathrm{C}$. Thereafter, 3 milliliters $(\mathrm{ml})$ of distilled water was added to the control and $3 \mathrm{ml}$ of water soluble salt (sodium chloride) (EC: $15 \mathrm{ds} \cdot \mathrm{m}^{-1}$ ) was added to salt treatment and the seeds were covered with a filter paper, and were placed in a germinator for 4 days at $27{ }^{\circ} \mathrm{C}$. Moreover, the following physiological and biochemical parameters were measured: percentage of germination, root length, fresh and dry weight, the phenolic compounds, glycine betaine, proline, the concentration of $\mathrm{Na}^{+}$ions, $\mathrm{K}^{+}$, and calcium.

Assessment of germination percentage: The germination of seeds was calculated after 4 days by Equation 1. It should be noted that seeds with radicle length of $1 \mathrm{~mm}$ or more were considered as germinated seeds (Weston et al., 2004).

$$
\mathrm{PG}=100 \mathrm{n} / \mathrm{N}
$$

where $\mathrm{N}$ is the total number of seeds, $\mathrm{n}$ is the number of germinated seeds and $\mathrm{PG}$ is the Percentage of Germination.

Measuring the length of radicle seedlings: The radicle length of the seedling ( $\mathrm{mm})$ was measured (4 days) after the initial radicle emergence.

Measurement of the fresh and dry weight of seedlings: Seedlings from each treatment (4 repetitions) were randomly selected and their fresh weight was measured using a Digital Scale (gram). To determine the dry weight, seedlings from each treatment (4 repetitions) were placed in the oven at $90{ }^{\circ} \mathrm{C}$ for $24 \mathrm{~h}$, followed by weighing.

Assessment of proline (Bates et al., 1973): 0.2 gr of frozen seedlings was homogenized in $3 \%$ sulfosalicylic acid, and the homogenate was centrifuged at $10000 \mathrm{rpm}$ (revolutions per minute). The supernatant was used for the estimation of proline content. The reaction mixture $\left(2 \mathrm{ml}\right.$ acid ninhydrin and $2 \mathrm{ml}$ of glacial acetic acid) was heated at $100{ }^{\circ} \mathrm{C}$ for $1 \mathrm{~h}$. 
The reaction mixture was extracted with $4 \mathrm{ml}$ of toluene and absorbance was read at 520 nm.

Phenolic compounds assay (Matta and Giai, 1969): The samples were boiled in $10 \mathrm{ml}$ alcohol $80 \%$ for $15 \mathrm{~min}$ and then, centrifuged for $15 \mathrm{~min}$ at $3000 \mathrm{~g} .5 \mathrm{ml}$ of diluted foline (1:3) and $10 \mathrm{ml}$ of saturation $\mathrm{Na}_{2} \mathrm{CO}_{3}$ were added to $5 \mathrm{ml}$ of this solution. Samples were incubated at $25{ }^{\circ} \mathrm{C}$ for $10 \mathrm{~min}$ and then, centrifuged for $15 \mathrm{~min}$ at $4000 \mathrm{~g}$. Supernatant absorption was determined at $640 \mathrm{~nm}$. The standard curve of catechol was used to determine the content of phenolic compounds (milligram / gram dry weight: mg. $\mathrm{g}^{-1} \mathrm{FW}$ ).

Measurement of glycine betaine content (Sairam et al., 2004): 0.5 gr dried powder of seeds was distilled in $20 \mathrm{ml}$ water and shaken at $25^{\circ} \mathrm{C}$. The samples were filtered by filter paper and diluted with an equal ratio of sulfuric acid 2 N. 2 ml was separated and mixed with $8.0 \mathrm{ml}$ of iodide - cold iodine $\mathrm{K}^{+}$(Lugols). The solution was placed in a refrigerator for $16 \mathrm{~h}$ and was centrifuged at $3000 \mathrm{rpm}$ for $30 \mathrm{~min}$. $1 \mathrm{ml}$ of the upper phase was separated and dissolved with $9 \mathrm{ml}$ of 2,1-dichloroethane. The samples were vertex and after $2.5 \mathrm{~h}$, its absorption was read at $365 \mathrm{~nm}$ and then, the glycine betaine content (micromol / gram dry weight: $\mu \mathrm{mol} / \mathrm{g} \mathrm{DW}$ ) was calculated using Equation 2.

$$
\mathrm{C}=\mathrm{Abs} \times 0.00017+0.014636
$$

Measurement of $\mathrm{Na}^{+}$and $\mathrm{K}^{+}$(Williams and Twine, 1960): $1 \mathrm{gr}$ of fresh material was placed in the oven at $80{ }^{\circ} \mathrm{C}$ for $48 \mathrm{~h}$. Thereafter, it was put in an electric furnace at $600{ }^{\circ} \mathrm{C}$ for $6 \mathrm{~h}$. Subsequently, after weighting, the ashes was dissolved in $1 \mathrm{ml}$ of hydrochloric acid $6 \mathrm{~N}$, using a stirrer. Next, the samples were filtered and diluted with distilled water to a volume of $50 \mathrm{cc}$. Then, the amount of $\mathrm{Na}^{+}$and $\mathrm{K}^{+}$were determined using a flame photometer and a standard curve (gram / gram dry weight: g. $\mathrm{g}^{-1} \mathrm{DW}$ ).

Measurement of $\mathrm{Ca}^{2+}$ ions (Manteghi et al., 1987): $10 \mathrm{ml}$ mineral extraction plant was poured into Erlenmeyer flasks and then, $2 \mathrm{ml} \mathrm{NaOH} 4$ normal was added and $3.0 \mathrm{gr}$ Murexide powder was added. Then, the titration was performed using EDTA 0.01 normal to change its color to purple. This process was performed in the presence of calcium chloride solution as control. The value of $\mathrm{Ca}^{2+}$ as gram per gram of dry matter was calculated using the formula (g. $\left.\mathrm{g}^{-1} \mathrm{DW}\right)$.

\section{Statistical analysis}

The data was represented as mean \pm standard deviation (SD). The experiment was conducted using a completely randomized design with Four replicates $(n=4)$ having twenty seeds of each replicate. The data were statistically treated by one-way analysis of variance (ANOVA) and the mean values were compared using Duncan's test at $\mathrm{P}<0.05$ to establish significant differences between each treatment and control.

\section{Results}

Pix, salinity effect and their influence on the germination percentage, radicle length, fresh and dry weight

The results showed that germination percentage and radicle length were reduced under salinity stress in three cultivars compared with the control. Also, the use of Pix resulted in a significant increase in germination percentage compared with the control in all three 
cultivars and among them, the rate of increase of Latif and Kashmar cultivars was more than that of the Sahel cultivar (Fig. 1).
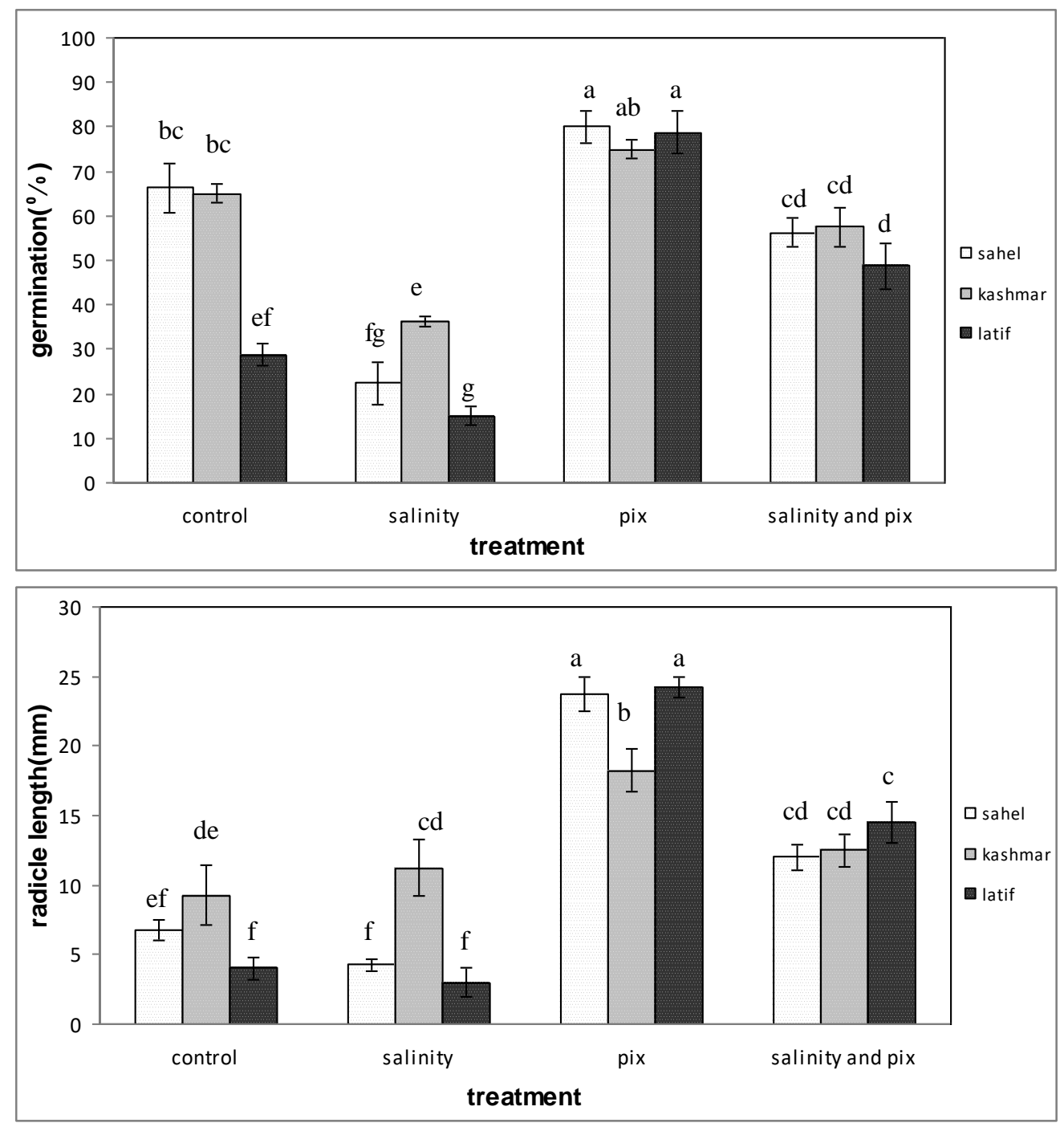

Figure 1. Effect of Pix, salinity and their interaction on the percentage of germination and radicle length. *Average with the same letters was not statistically significant ( $p \geq 0.05)$

Figure 2 shows that Sahel cultivar is sensitive to salinity and its fresh weight and dry weight decreased under salt stress but the use of Pix was very useful for salt stress tolerance. On the other hand, the fresh and dry weights of Latif cultivar were increased under Pix treatment alone as well as Pix and salinity combination treatments.

Effect of Pix, salinity and their interaction on the amount of seed phenol in new cultivars of cotton seedlings

The results showed that the phenolic compounds in Sahel cultivar treated with Pix presented a significant increase compared with the control treatment. Also, the phenolic compounds in all the treatments were increased in Latif and Kashmar cultivars in comparison with the control (Fig. 3). 


\section{Effect of Pix, salinity and their interaction on the glycine-betain content}

Figure 4 shows that the use of Pix and salinity combination caused an increase in the glycine betaine content in the three cultivars. Despite the fact that the Sahel cultivar is sensitive to salt stress, the highest glycine betaine content belonged to this cultivar.
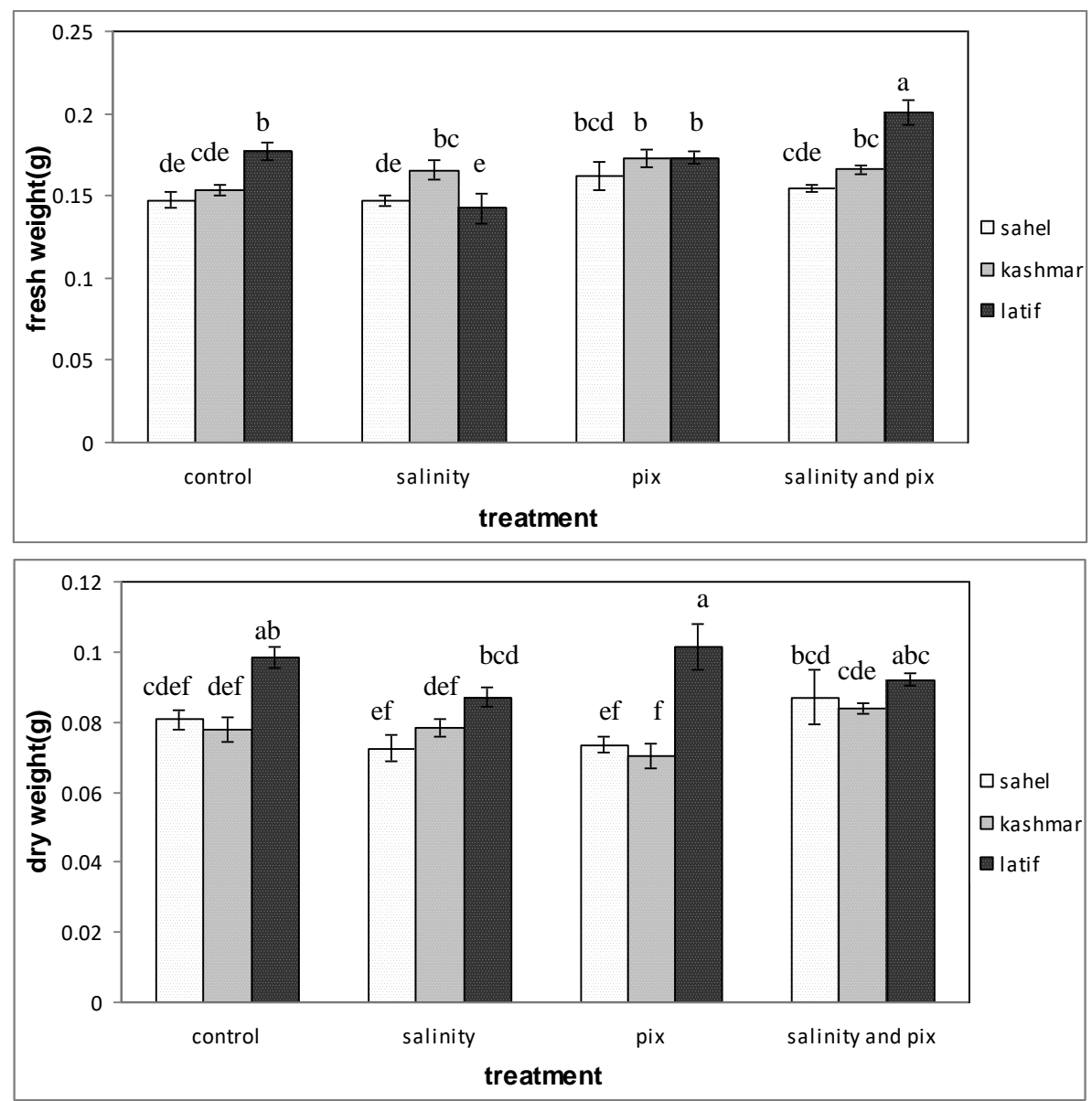

Figure 2. Effect of Pix, salinity and their interaction on the fresh and dry weights

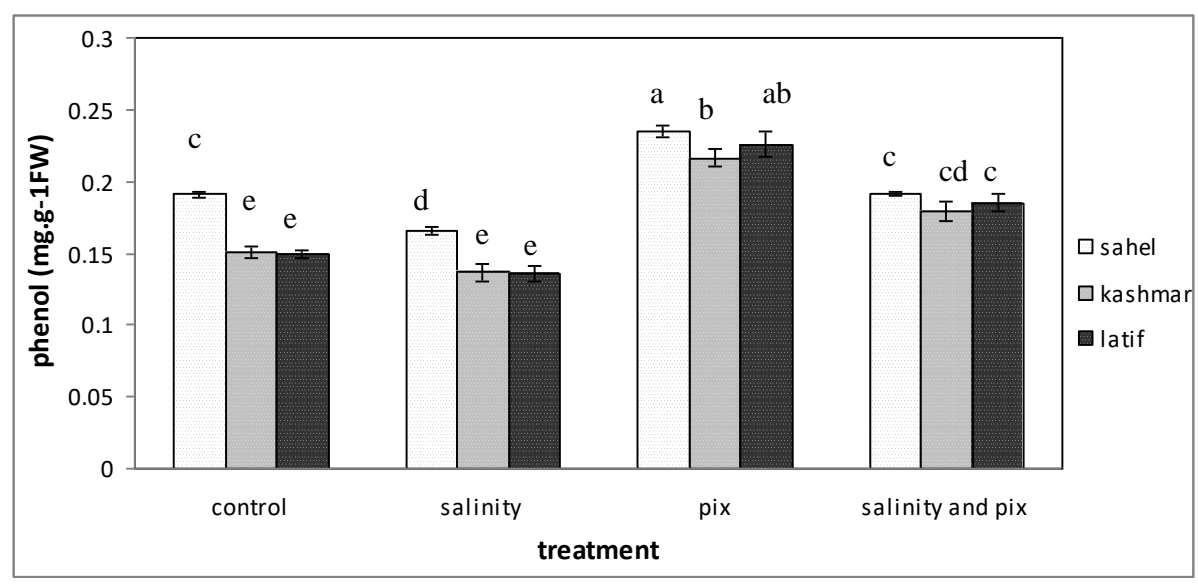

Figure 3. Effect of Pix, salinity and their interaction on the amount in phenol of new cultivars of cotton seedlings 


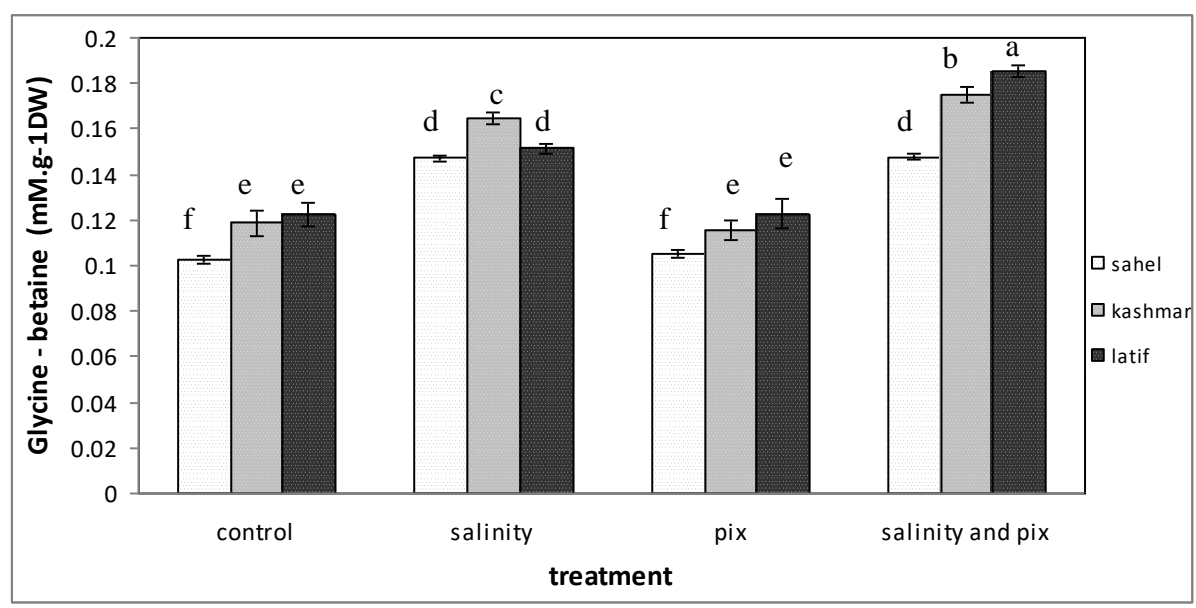

Figure 4. Effect of Pix, salinity and their interaction on the amount of Glycine - betaine in new cultivars of cotton seedlings

\section{Effect of Pix, salinity and their interaction on the amount of proline}

The results showed that the proline content had a significant increase in all three cultivars in the different treatments compared with the control treatment, but the proline content in cultivars of Kashmar and Latif was more compared to the sensitive cultivar of Sahel (Fig. 5).

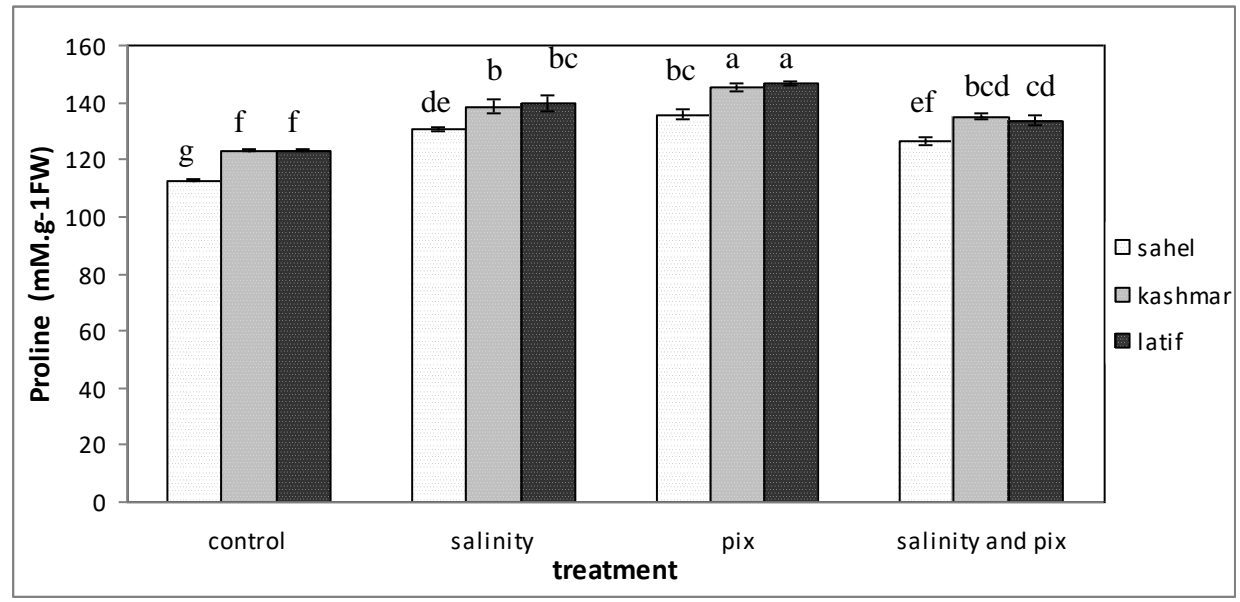

Figure 5. The effect of Pix, salinity and their interaction on the amount of proline in new cultivars of cotton seedlings

\section{Effect of Pix, salinity and their interaction on the amount of $\mathrm{Na}^{+}$and $\mathrm{K}^{+}$in new cultivars of cotton seedlings}

The results of this research showed that the amount of $\mathrm{Na}^{+}$in all three cultivars in different treatments had a significant increase compared with the control treatment. The amount of $\mathrm{Na}^{+}$in Latif and Kashmar cultivars was less than in the Sahel cultivar. Also, the amount of $\mathrm{K}^{+}$caused a significant decrease in the Sahel cultivar in all three treatments compared to the control treatment (Figs. 6 and 7). 


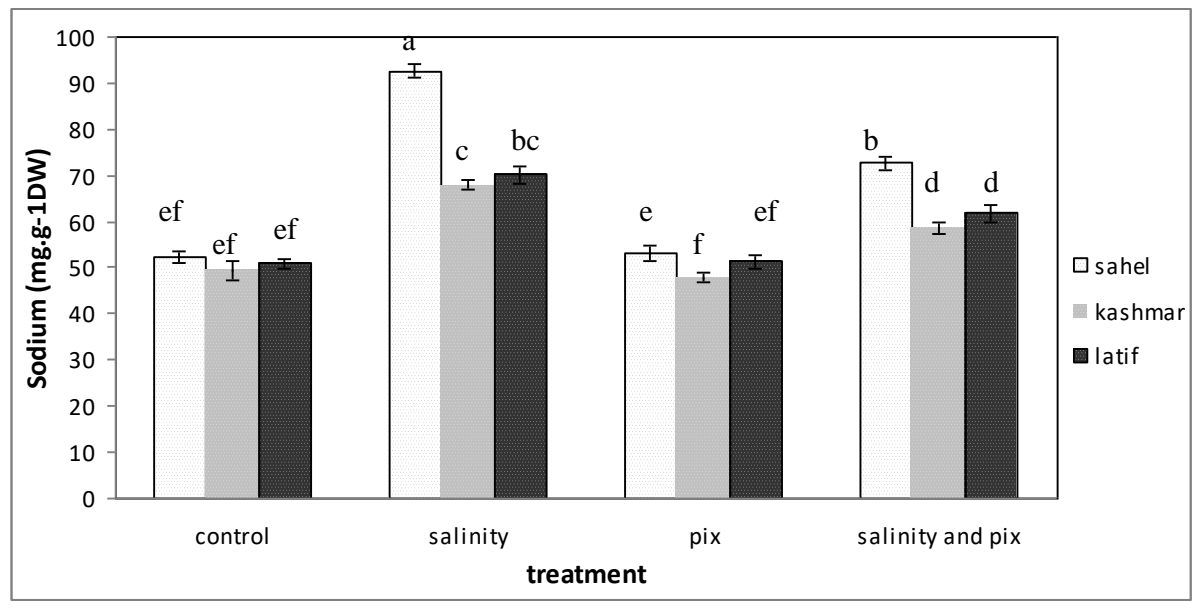

Figure 6. The effect of Pix, salinity and their interaction on the amount of $\mathrm{Na}^{+}$of new cultivars of cotton seedlings

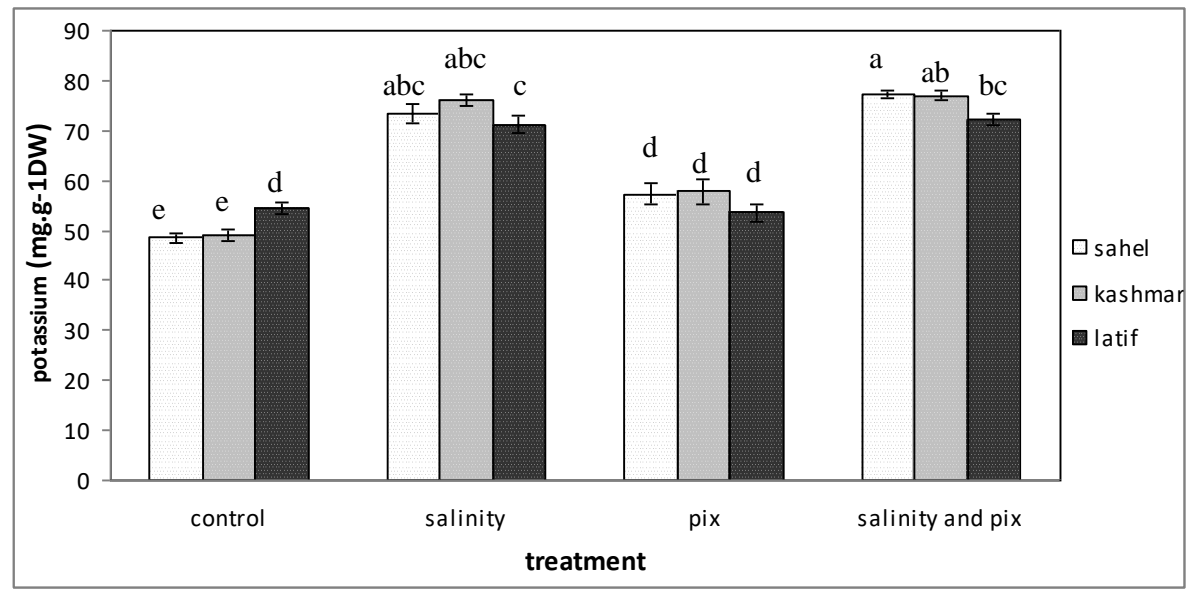

Figure 7. The effect of Pix, salinity and their interaction on the amount of $K^{+}$in new cultivars of cotton seedlings

\section{Effect of Pix, salinity and their interaction on the amount of $\mathrm{Ca}^{2+}$ in new cultivars of cotton seedlings}

Compared to the control treatment, the results indicated that the amount of $\mathrm{Ca}^{2+}$ had a significant increase in all three cultivars in different treatments (Fig. 8).

\section{Discussion}

Previous studies showed that the length of root and stem was significantly reduced under salinity (Habib et al., 2014; Pervaiz et al., 2007; Noor et al., 2001; Ibrahim et al., 2007; Weiping et al., 2009; Rezaei et al., 2005). Moreover, the fresh and dry weight of the root and stem was reduced in cotton cultivar (Habib et al., 2014; Ibrahim et al., 2007; Saleh, 2011). In addition, the results of previous studies showed that salinity stress resulted in a decrease in germination percentage and growth parameters of cotton seedling in Sepid 2 cultivar. Also, priming with Pix improved injuries that were caused 
by salinity on these parameters (Alishah et al., 2012). The most important effect of Pix on cotton was longitudinal growth prevention (Singh, 2010). Pix can cause changes in seed physiology and affect the cell wall. Reviews on the germination percentage showed that seeds treated with Pix had significantly higher germination percentage compared with the control (Niakan et al., 2012). The findings revealed that at high concentrations of salt, the use of Pix resulted in improved germination and increased physiological characteristics including root length, as well as fresh and dry weight (Alishah et al., 2012). Regarding the obtained results, there was an increase in the dry weight of the seedlings due to an increase in the length of the radicle when Pix was used. The priming of seeds with Pix before planting can be a suitable method in cotton production that leads to increase in root length in the early stages of germination.

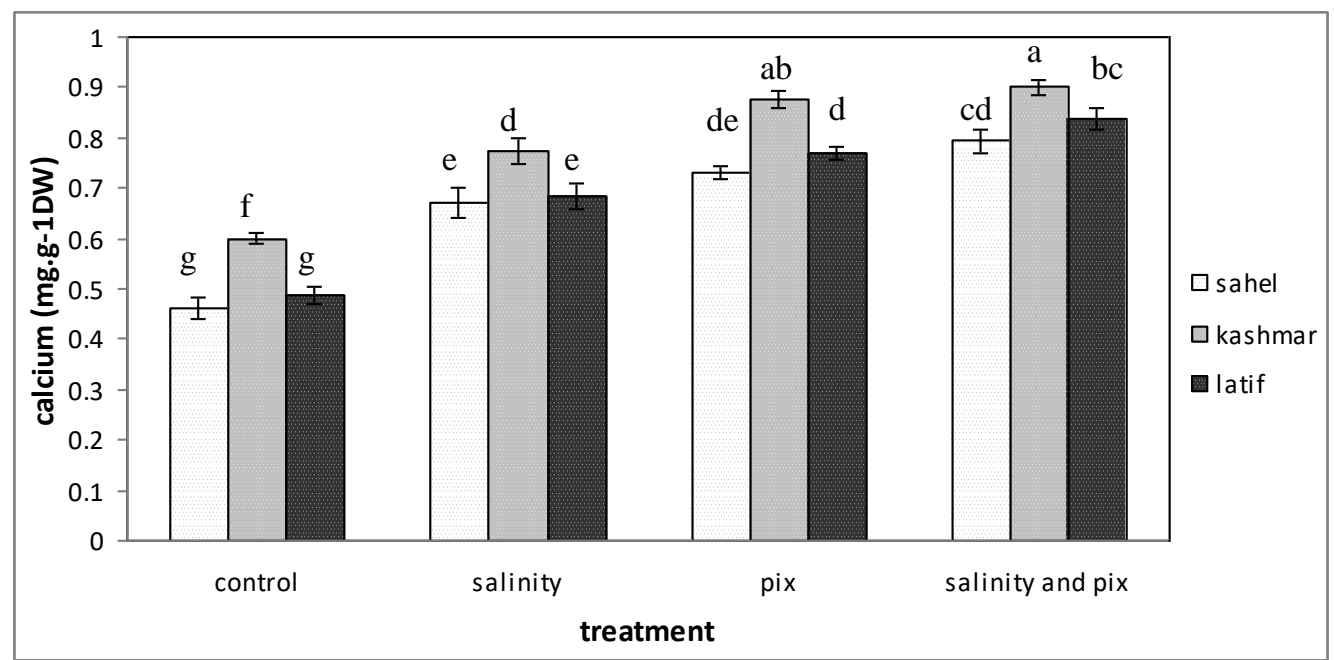

Figure 8. The effect of Pix, salinity and their interaction on the amount of $\mathrm{Ca}^{2+}$ in new cultivars of cotton seedlings

Phenolic compounds are different secondary metabolites that exist in large quantities in plant tissues until the plant can cope against reactive oxygen species, these compounds play an antioxidant role and protect plants from the oxidizing action of malicious free radicals (Grace and Logon, 2000; Zhu, 2000). Previous researches showed that salinity stress in barley seedlings leads to a decrease in phenolic compounds, flavonoids and growth (Ali and Abbas, 2003). Tamer and Abdel-al (2012) in their research findings on the content of the phenolic compounds of barley seedlings under the $\mathrm{NaCl}$-salinity stress showed that the content of phenolic compounds was reduced. These findings are based on the fact that the reduction of phenolic compounds in the Sahel cultivar under salinity stress was consistent with the results of the present study.

The results showed that the amount of phenolic compounds increased in Kashmar and Latif Cultivars subjected to Pix and salinity along with Pix treatments. This issue indicated that seed treatment with Pix in saline or non-saline conditions caused the increase of phenolic compounds that were resistant to stress. The first step in the phenylpropanoids metabolism was deamination of L-phenylalanine of cinnamic acid by phenylalanine ammonia-lyase (PAL) (Iijima et al., 2004; Achnine et al., 2004). PAL is an enzyme intermediate between the primary and secondary metabolism of 
phenylpropanoids (Adams, 2001). Metabolites that occur as a result of PAL activity are classified as phenolic derivatives. The results of this study demonstrated that the amount of glycine - betaine increased in all three treatments in the Sahel cultivar compared to the control treatment.

In plants, osmotic adjustment takes place through the production of various types of compatible organic solvents and some inorganic ions. These materials may insulate the injuries of plant cells through osmotic stress by modulating and maintaining membrane fluidity and stability of proteins or enzymes (Bohnert and Jensen, 1996).

Glycine betaine is one of the most abundant compatible organic substances in plants (Weibing and Rajashekar, 1999). In many plants, such as spinach, barley, wheat and sorghum, there is an increase in glycine betaine in response to various stresses (Rhodes and Hanson, 1993; Yang et al., 2003; McNell et al., 2001; Hellman et al., 2000; Ashraf and Foolad, 2007; McNell et al., 2001; Gorham et al., 2000).

Glycine betaine is naturally accumulated in some plants whereas in others, it is not produced even under stress condition (Ashraf and Foolad, 2007). However, it appears that the moderating role of glycine betaine depends on many factors including product type, time, its application, and the environmental conditions (Makela et al., 1998). The glycine betaine concentration is changing in different species and are used as an osmotic regulator (Agastian et al., 2000).

An investigation revealed that an increase in the different levels of glycine betaine in cotton under salinity is different in some variety compared to other varieties that accumulate higher amounts of proline and glycine betaine (Desingh and Kanagaraj, 2007).

With increasing salinity in two cotton cultivars, (Aria- Anubam and LRA - 5166), the amount of glycine betaine increased in both cultivars (Desingh and Kanagaraj, 2007).

The results of this study showed that the amount of glycine betaine in the seedling was significantly increased as compared to the control. This combination is one of the physiological resistances against salinity in the early stages of germination.

Studies have shown that the osmotic stress injuries caused by salinity and $\mathrm{NaCl}$ can be reduced with the use of glycine betaine and this issue depends on the concentration and time of conducting this research (Ashraf, 2009). Interestingly, plants under salinity stress are divided into three categories of plants with resistance strategy via proline or glycine betaine or both (Larher et al., 1996). It appears that Kashmar and Latif cultivars are the apparently tolerant ones in the salinity treatment and showed increase in the glycine betaine. Hence, they could be regarded among plants that act with Resistance strategy through the accumulation of glycine betaine. Proline is an amino acid which is widely accumulated in higher plants under salinity and drought stress as an osmotic regulator (Abraham et al., 2003; Rontein et al., 2002; Rontein et al., 2002; Fahramand et al., 2014; Ashraf and Harris, 2004; Mansour et al., 2005b) and substantially contributes to osmotic cytoplasm adjustment, and to the stability of the membrane and membrane process.

The results showed that salinity increased the amount of proline in alfalfa (Parida et al., 2004), cotton (Desingh and Kanagaraj, 2007; Mirghasemi et al., 2010), as well as different ecotypes of fox berry plant in the germination stage (Nad Ali et al., 2014). Some studies have indicated that salinity stress causes the excessive accumulation of proline in the Sayochra cultivar of cotton and show that this cultivar follows the proline accumulation strategy in salt tolerance (Kumar, 1987). Regarding the increase in proline and glycine betaine content in Kashmar and Latif cultivars that are apparently tolerant 
in salinity treatment; therefore, an increase in these compounds in the cell relieves stress for osmotic moderation. Kashmar and Latif cultivars accumulate proline and glycine betaine that can be considered part of the plants that act through resistance strategy.

In this research, the use of Pix in saline condition caused a decrease in seedling proline content, as compared to the treatment of Pix and saline treatment. It is possible that the decrease in the amount of proline in saline conditions is as a result of the activation of the enzyme proline oxidase that has a role in the conversion of proline to glutamate. Glutamate is used in the biosynthesis of other amino acids for protein synthesis (Mundree et al., 2002).

Even at low concentrations, $\mathrm{Na}^{+}$ions are toxic inside the plant and limit the metabolic activity while $\mathrm{K}^{+}$ion is known as one of the macronutrients essential for membrane maintenance and enzyme activity. The high concentrations of $\mathrm{Na}^{+}$results in the reduced absorption of other nutrients into the soil (Silber bush and Ben-Asher, 2001). $\mathrm{Na}^{+}$ions occupy $\mathrm{k}^{+}$transfer channels in the plasma membrane of root cells, thereby preventing the absorption of $\mathrm{K}^{+}$(Tester and Davenport, 2003) and lead to reduced absorption of other essential elements (Kaymakanova and Stoeva, 2008).

A research of resistant and susceptible genotypes of cotton to salt indicated that the amount of $\mathrm{Na}^{+}$was significantly increased under salinity condition and resulted in a decrease in the amount of $\mathrm{K}^{+}$(Habib et al., 2014). The ratio of $\mathrm{K}^{+}$to $\mathrm{Na}^{+}$has been proposed as a success indicator in salt resistance. The terrestrial life of plants depends on high-affinity $\mathrm{K}^{+}$uptake systems and benefits from high-affinity $\mathrm{Na}^{+}$uptake systems. In plants, both systems have received extensive attention during recent years and a clear insight of their functions is emerging. Some plant HAK transporters mediate highaffinity $\mathrm{K}^{+}$uptake in yeast, mimicking $\mathrm{K}^{+}$uptake in roots, while other members of the same family may be $\mathrm{K}^{+}$transporters in the tonoplast. In parallel with the HAK transporters, some HKT transporters mediate high-affinity $\mathrm{Na}^{+}$uptake without cotransporting $\mathrm{K}^{+}$. HKT transporters have two functions: (i) to take up $\mathrm{Na}^{+}$from the soil solution to reduce $\mathrm{K}^{+}$requirements when $\mathrm{K}^{+}$is a limiting factor, and (ii) to reduce $\mathrm{Na}^{+}$accumulation in leaves by both removing $\mathrm{Na}^{+}$from the xylem sap and loading $\mathrm{Na}^{+}$ into the phloem sap (Rodriguez and Rubio, 2006). Although there is no data available on the presence of HAK in Cotton but perhaps, there are effective mechanisms to increase transcription of these proteins that may be due to the adjusting effect of $\mathrm{K}^{+}$to maintain osmotic salinity stress (Yokoi, 2002; Rodriguez and Rubio, 2006). The results indicated that in the sensitive cultivar of Sahel, the number of $\mathrm{Na}^{+}$ions is higher in plants than in the other two cultivars, Latif and Kashmar. Therefore, there is more damage to plants. However, the $\mathrm{Na}^{+}$content was increased in the Latif and Kashmar cultivars as compared to the control, but this increase was less compared to the sensitive Sahel cultivar. Indeed, the number of ions in the plant was reduced when treatment with Pix and the amount of damage was decreased, as well. It can be said that in the sensitive cultivar of Sahel, $\mathrm{K}^{+}$was not increased but this amount was increased in Latif and Kashmar cultivars. This result is encouraging and shows that two cultivars of Kashmar and Latif were resistant to salinity and thus, the amount of $\mathrm{K}^{+}$was increased in order to reduce the losses of the $\mathrm{Na}^{+}$adsorption.

As a result of the importance of $\mathrm{Ca}^{2+}$ permeability and the properties of selective membranes, high levels of $\mathrm{Na}^{+}$to $\mathrm{Ca}^{2+}$ ions in tissues can cause changes in the cell activities (Ashraf, 2004; Mahmoud, 2009). $\mathrm{Ca}^{2+}$ is the main component of the wall and preserve the integrity of the plasma membrane and maintains coherence in roots and shoots during stress (Ashraf, 2004; Mahmoud, 2009; Ashraf et al., 2008). 
$\mathrm{Ca}^{2+}$ is an immobile element which remains during the growing season in older tissues, and transfers carbohydrates, facilitates the absorption of nitrogen and reduces the harmful effects of $\mathrm{Na}^{+}$(Ashraf, 2008). Cell wall formation and its development is impossible without $\mathrm{Ca}^{2+}$ (Taiz and Zeiger, 1998). Research has shown that $\mathrm{Ca}^{2+}$ plays a significant role in the salinity resistance of cotton and it will reduce the toxic effect of $\mathrm{Na}^{+}$with a decrease of $\mathrm{Ca}^{2+}$ (Cramer et al., 2002). Pix cause an increase in the concentration of $\mathrm{Ca}^{2+}$ ion in the tissues and $\mathrm{K}^{+}$ion at the root. Pix controls the vegetative and reproductive growth by reducing the concentration of gibberellic acid in the plant and reducing the length of internodes (Havargi, 2007; Jonathan, 2006; Joseph, 2006). The results showed that the amount of $\mathrm{Ca}^{2+}$ in each cultivar was increased with increasing salinity compared to the control, but this increase was more in Latif and especially, Kashmar cultivars. This suggests that the mechanism of $\mathrm{Ca}^{2+}$ ion to reduce $\mathrm{Na}^{+}$ion was used in these two cultivars under stress conditions compared to the Sahel cultivar. Therefore, these two cultivars, and especially Kashmar cultivar, are considered as the resistant cultivar to salinity.

The results of this research indicated that Latif and especially, Kashmar cultivars are considered as resistant cultivars to salt stress. The results of this study showed that growth parameters including germination percentage and radicle length in the Latif and especially, Kashmar cultivars had a significant increase compared to the sensitive cultivar of Sahel. Considering the amount of dry and fresh weight of these two cultivars in particular, Latif cultivar was higher than Sahel cultivar.

The number of phenolic compounds, proline and glycine betaine in these two cultivars have increased with increasing salinity compared to the control and Sahel cultivar. Also, in these two cultivars, the amount of $\mathrm{Na}^{+}$ion absorption was lower than that of the Sahel cultivar while the absorption amount of $\mathrm{K}^{+}$and $\mathrm{Ca}^{2+}$ ions increased compared to that of the Sahel cultivar and control treatment. In Pix treatment as well as Pix and salinity treatment, phenolic compounds and proline increased in the two cultivars of Kashmar and Latif compared to the controls and Sahel cultivar. In Pix and salinity treatments, the amount of proline was increased in salinity treatment and control. The $\mathrm{Na}^{+}$absorption ratio in the Latif and Kashmar cultivars was decreased in salinity and Pix treatment compared to the salinity treatment. Pix and salinity treatment cause increase in uptake of $\mathrm{K}^{+}$compared to salinity treatment in the Kashmar cultivar. Indeed, in Pix and salinity treatment, the amount of $\mathrm{Ca}^{2+}$ in all cultivars, especially Kashmar and Latif was higher compared to the salinity treatment. Therefore, it can be concluded that priming seeds with Pix can lead to a decrease in salinity, especially in resistant cultivars. The Latif cultivar and especially, Kashmar cultivar showed more resistance to the salinity; hence both are considered as resistant cultivars. Indeed, the priming of seed with Pix has a significant effect on increasing resistance to salinity in these cultivars.

As reported in Figure 9, $\mathrm{Na}^{+}$in the aerial parts was reduced through priming of Kashmar cultivar with Pix and therefore, the number of these toxic ions decreased. Interestingly, it would occur due to the number of reasons including low absorption of $\mathrm{Na}^{+}$by the roots, reflux $\mathrm{Na}^{+}$from root seedlings, inhibition of $\mathrm{Na}^{+}$transport to the aerial parts and the choice of $\mathrm{K}^{+}$and $\mathrm{Ca}^{2+}$ as well as the removal of $\mathrm{Na}^{+}$. Increasing the amount of glycine betaine, proline and phenolic compounds in the seedlings of Kashmar cultivars along with reducing the amount of $\mathrm{Na}^{+}$ions in the aerial parts of plants cause less damage of the membrane system and better ion balance in these cultivars. These factors result in an increase in the germination, radicle length, fresh and 
dry weight in the seedlings of Kashmar cultivar and finally, had better performance than other cultivars (Fig. 9).

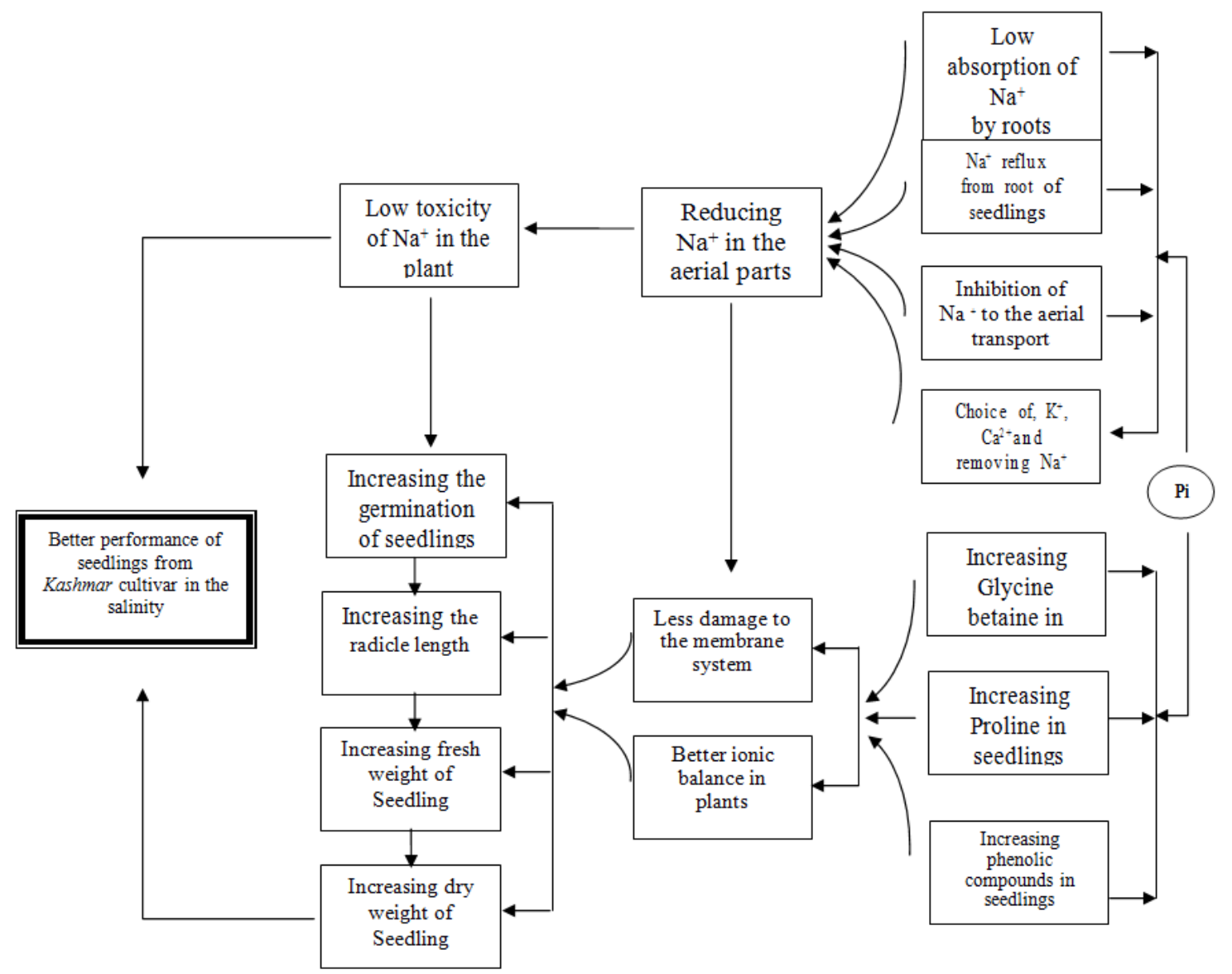

Figure 9. The effect of Pix on the resistance of salinity in Kashmar cultivar at seedling stage

\section{Conclusion}

The manipulation of cotton plant architecture using plant growth regulators such as Pix can be an agronomic strategy for obtaining high yields. The results indicated that priming Pix improved the physiological and biochemical parameters of cotton (especially in the Kashmar and Latif cultivars) in terms of salinity.

The $\mathrm{NaCl}$ stress caused changes in physiological and biochemical traits and reduced germination percentage, radicle length, dry and fresh weight, phenolic compounds, proline and glycine betaine in the Latif and Kashmar cultivars, whereas the treatment of cottonseed with mepiquat chloride in saline stress resulted in significant increase in these parameters. The amount of $\mathrm{Na}^{+}$in all three cultivars in different treatments had a significant increase compared to the control treatment.

The amount of $\mathrm{Na}^{+}$ion absorption was lower in Kashmar and Latif cultivars compared to the Sahel cultivar while the amount of $\mathrm{K}^{+}$and $\mathrm{Ca}^{2+}$ ions absorption was increased in the two mentioned cultivars compared to the Sahel cultivar.

It appears that Pix treatment in $\mathrm{NaCl}$ stress can be one of the tolerance mechanisms in cotton (especially in the Kashmar and Latif cultivars) which requires further research. 
Considering the fact that in the present study, cotton seed priming with Pix was used, it is recommended that this experiment be carried out with a Pix spray on the plant. Also, the morphological and genetic parameters of the plant in vegetative and reproductive stages, as well as the final yield of the plant should be investigated. Also, given the fact that in the current and traditional agriculture system, cotton is pruned to prevent it from extra growth, it is recommended that the relationship between Pix level and pruning should be investigated.

\section{REFERENCES}

[1] Abraham, E., Rigo, G., Szekely, G., Nagy, R., Koncz, C., Szabados, L. (2003): Lightdependent induction of proline biosynthesis by abscisic acid and salt stress is inhibited by brassinosteroid in Arabidopsis. - Plant Mol. Biol. 51: 363-372.

[2] Achnine L, Blancaflor, E. B., Rasmussen, S., Dixon, R. A. (2004): Colocalization of Lphenylalanineammonia-lyase and cinnamate 4-Hydroxylase formetabolic channeling in phenylpropanoidbiosynthesis. - Plant Cell 16: 3098-3109.

[3] Agastian, P., Kingsley, S. J., Vivekanandan, M. (2000): Effect of salinity on photosynthesis and biochemical characteristics in mulberry genotypes. - Photosynthetica 38: 287-290.

[4] Adams, R. P. (2001): Identification of Essential Oils Components by Gas Chromatography/ Quadrupole Mass Spectroscopy. - Allured Publishing Co., Illinois, USA, pp. 119-146.

[5] Ali, R. M., Abass, H. M. (2003): Response of salt stressed barly seedling to phenylurea. Plant Soil Environment 49(4): 158-162.

[6] Alishah, O., Nyakan, M., Ghafory, S. (2012): The effect of priming Pix regulators on growth and antioxidant systems of cotton seedlings at different levels of salinity . Journal of iranian Ecophysiological Research(Plant Sciences Research) 23(6): 22-33.

[7] Ashraf, M. (2004): Some important physiological selection criteria for salt tolerance in plants. - Flora 199(5): 361-376.

[8] Ashraf, M. (2009): Biotechnological approach of improving plant salt tolerance using antioxidants as markers. - Biotech. Adv. 27: 84-93.

[9] Ashraf, M., Foolad, M. R. (2005): Pre-sowing seed treatment-a shotgun approach to improve germination, plant growth, and crop yield under saline and non-saline conditions. - Advances in Agronomy 88: 223-271.

[10] Ashraf, M., Foolad, M. R. (2007): Role of glycine betaine and proline in improving plant abiotic stress resistance. - Environ. Exp. Bot. 59: 206-216.

[11] Ashraf, M., Harris, P. J. (2004): Potential biochemical indicators of salinity tolerance in plants. Plant Sience 166: 3-16.

[12] Ashraf, M., Ozturk, M., Athar, H. R. (2008): Salinity and Water Stress. (Tasks for Vegetation Science Series 44: Improving Crop Efficiency). Springer-Verlag, Netherlands.

[13] Bates, L. S., Walderen, R. D., Taere, I. D. (1973): Rapid determination of free proline for water stress studies. - Plant Soil 39: 205-207.

[14] Bohnert, H. J., R. G. Jensen (1996): Metabolic engineering for increased salt tolerancethe next step. - Australian journal of Plant Physiology 23: 661-666.

[15] Cramer, G. R. (2002): $\mathrm{Na}^{+}-\mathrm{Ca}^{+}$Interactions under Salinity Stress. - In: Luchli, A., Lüttge, U. (eds.) Salinity: Environment - Plants - Molecules. Kluwer Academic Publishers, Dordrecht, pp. 205-227.

[16] Demir Kaya, M., Okcu, G., Atak, M., Yakup, C.(2006): Seed treatments to overcome salt and drought stress during germination insunflower (Helianthus annuus L.). -Europ. J. Agronomy 24(2006): 291-295. 
[17] Desingh, R., Kanagaraj, G. (2007): Influence of Salinity Stress on Phptpsynthesis and Antioxidative Systems in Two Cotton Varieties. - Department of Botany, Annamalai University, Annamalai Nagar, TN, India.

[18] Fahramand, M., Mahmoody, M., Keykha, A., Noor, M., Rigi, K. (2014): Influence of abiotic stress on proline, photosynthetic enzymes and growth. - International Research Journal of Applied and Basic Sciences 8(3): 257-265. www.irjabs.com.

[19] Godfery,W. N., Onyango, J. C., Beck, E. (2004): Sorghum and salinity: II. Gas exchange and chlorophyll fluorescence of sorghum under salt stress. - Crop Science 44: 806-811.

[20] Gorham, J., Jokinen, K., Malik, M. N. A., Khan, I. A. (2000): Glycine betaine treatment improves cotton yields in field trials in Pakistan. - Proceedings of the World Cotton Research Conference II, Athens, Greece.

[21] Grace, S., Logan, B. A. (2000): Energy dissipation and radical scavenging by the plant phenylpropanoid pathway. - Philosophical Transaction of the Royal Society of London B 355: $1499-1510$.

[22] Gulzar, S., Ajmalkhan, M. (2001): Seed germination of a halophyte grass Aeluropus lagopoides. - Annals of Botany 87: 319-324.

[23] Habib, F., Akram, Z., Akhtar, J., Hussain, S., Mansoor, M. (2014): Assessment of variations in growth and ionic concentration of salt tolerant and sensitive cotton genotypes. - Sci. Agri. 7(2): 105-110.

[24] Hasegawa, P. M., Bressan, R. A., Zhu, J.-K., Bohnert, H. J. (2000): Plant cellular and molecular responses to high salinity. - Annu. Rev. Plant Physiol. Plant Mol. Biol. 51: 463-499.

[25] Havargi, R. (2007): Mitigation drought stress through plant growth regulators in Vesicular arbuscular mycorrhizae (VAM) cotton. - Master of Science (Agriculture) Thesis in Crop Physiology. Department of Crop Physiology, College of Agriculture, Dharwad University of Agricultural Science.

[26] Hellman, H., D. Funk, D. Rentsch, W. B. Frommer (2000): Hypersensitivity of an Arabidopsis sugar signaling mutant toward exogenous proline application. - Plant Physiol. 123: 779-790.

[27] Ibrahim, M., Akhtar, J., Younis, M., Riaz, A. M., Anwar-ul-Haq, M., Tahir, M. (2007): Selection of cotton (Gossypium hirsutum L.) genotypes against $\mathrm{NaCl}$ stress. - Soil \& Environ. 26(1): 59-63.

[28] Iijima, Y., Rikanati, R. D., Fridman, E., Gang, D. R., Bar, E., Lewinsohn, E., Pichersky, E. (2004): The biochemical and molecular basis for the divergent in the biosynthesis of terpenes and phenylpropenes in the peltate gland of three cultivars of basil. - Journal of Plant Physiology 136: 3724-3736.

[29] Jaleel, C. A., Manivannan, P., Abdul Wahid, F., Al-Jubruni, H. J., Somasundaram, R., Panneerselvam, R. (2009): Drought stress in plants: a review on morphological characteristics and pigments composition. - International Journal of Agriculture \& Biology 11: 100-105.

[30] Jamali, S. S., Borzooei, A., Paknejad, F. (2015): Root characteristics, $\mathrm{Na}^{+}$to $\mathrm{K}^{+}$ratio and yield seven wheat genotypes under salt stress. - Science and Technology of Greenhouse Culture Magazine 5(20): 165-175.

[31] Jonathan, D. S., Alexander, M. S. (2006): Influence of plant density on cotton response to mepiquat chloride application. - Agro. J. 98: 1634-1639.

[32] Joseph, T. J., Johnson, T. P. (2006): Effect of mepiquat pentaborate on cotton cultivars with different maturities. - J. Cot. Sci. 10: 128-135.

[33] Jost, P., Whitaker, J. Steve, M. B., Bednarz, C. (2006): Use of Plant Growth Regulators as a Management tool in Cotton. - Georgia Cotton Production Guide, pp. 37-39.

[34] Kaya, C., Ak, B. E., Higgs, D., Murillo-Amador, B. (2002): Influence of foliar applied calcium nitrate on strawberry plants grown under salt stress western Himalaya. Industrial Crops and Products 27(3): 380-384. 
[35] Kaymakanova, M., Stoeva, N. (2008): Physiological reaction of bean plants (Phaseolus vulg. L) to salt stress. - Gen Appl Plant Physiol 34(3-4): 177-188.

[36] Khan, M. H., Panda, S. K. (2008): Alterations in root lipid peroxidation and antioxidative responses in two rice cultivars under NaCl-salinity stress. - Acta Physyol Plant 30: 91-89.

[37] Khan, M. H., Singha, L. B., Panda, S. K. (2002): Changes in antioxidant levels in Oriza sativa L. roots subjected to NaCl-salinity stress. - Acta Physyol Plant 24: 145-148.

[38] Koca, M., Bor, M., Ozdemir, F., Turkan, I. (2007): The effect of salt stress on lipid peroxidation, antioxidative enzymes and proline content of sesame cultivars. - Environ. Exp. Bot. 60: 344-351.

[39] Kook, H., Park, T. I., Khatoon, A., Rahman, S.,Yun, S. J. (2009): Avoidance of sodum accumulation in the shoot confers tolerance to salt stress in cultivarted barley. - Pak. J. Bot. 41(4): 1751-1758.

[40] Kumar, V., Mehta, N. P., Gohil, M. D. (1987): Investigation into some physiological parameters of cotton under water stress. - Ann. Arid Zone 26: 267-275.

[41] Larher, F., Rival-Garnier, N., Lemesle, P., Plasmman, M., Bouchereau, A. (1996): The glycinebetaine inhibitory effect on the osmoinduced proline respense of rape leaf discs. Plant Sci. 113: 21-31.

[42] Mahmoud, A. (2009): A new rapid and simple method of screening wheat plants at early stage of growth for salinity tolerance. - Pak. J. Bot. 41(1): 255-262.

[43] Makela, P., Jokinen, K., Kontturi, M., Peltonen-Sainio, P., Pheu, E., Somersalo, S. (1998): Foliar application of glycine betaine a novel product from sugar beet as an approach to increase tomato yield. - Industrial Crop Production 7: 139-148.

[44] Mansour, M. M. F., Al-Mutawa, M. M., Salama, K. H. A., Abou Hadid, A. F. (2005a): Salt Acclimation of Wheat Salt Sensitive Cultivar by Polyamines. - In: Ahmad, R., Malik, K. A. (eds.): Prospect for Saline Agriculture. Kluwer Academic Publishers, Dordrecht.

[45] Mansour, M. M., F. Z., Salama, M., Ali, A. F., Abou, H. (2005b): Cell and plant responses to $\mathrm{NaCl}$ in Zea Mays L. cultivars differing in salt tolerance. - Gen. Appl. Plant Physiol. 31(1-2): 29-41.

[46] Manteghi, N. (1987): Explanation methods and laboratory examination of soil and water samples. - Soil and Water Research Institute, Publication No. 168, Karaj, Iran.

[47] Masood, A., Shah, N. A., Zeeshan, M., Abraham, G. (2006): Differential response of antioxidant enzymes to salinity stress in two varieties of Azolla (Azolla pinnata and Azolla tilieuloides). - Env. Exp. Bot. 58: 216-222.

[48] Matta, A. G., Giai, I. (1969): Accumulation of phenol in tomato plant in effected by different forms of Fusarium oxysporum. - Phytphatol. 50: 512-513.

[49] McDonald, M. B. (2000): Seed Priming. - In: Black, M., Bewley, J. D. (eds.) Seed Technology and Its Biological Basis. Sheffield Academic Press Ltd., Sheffield, pp. 287325.

[50] McNell, S. D., Nuccio, M. L., Zeimark, M. J., Hanson, A. D. (2001): Enhanced synthesis of choline and glycine betaine in transgenic tobacco plants that overexpress phosphoethanolamine N-Methyltransferase. - Proc. Nat. Acad. Sci. USA 98: 1000110005.

[51] Meloni, D. A., Oliva, M. A., Martinez, C. A., Cambraia, J. (2003): Photosynthesis and activity of superoxide dismutase, peroxidase and glutathione reductase in cotton under salt stress. - Environ. Exp. Bot. 49: 69-76.

[52] Mer, R. K., Prajith, P. K., Pandya, D. H., Dandey, A. N. (2000): Growth of young plants of Hourdum Vulgare, Tritieum aeistium, Cicer arienum and Brassica Juncea. - J. Agronomy \& Crop Science186: 209-217.

[53] MirGhasemi, S. J., Rezaei, M., Alishah, A. S., Shabedin, M. (2010): Impact of salinity on the concentration of anthocyanins, proline and glycine betaine in commercial cultivars of cotton (Gossypium hirsutum L.). - Journal of Plant Sciences 13(1). 
[54] Mittler, R. (2002): Oxidative stress, antioxidants and stress tolerance. - Trends Plant Sci. 7: 405-410.

[55] Mundree, S. G., Baker, B., Bowla, S., Peters, S., Marias, S., Wilingen, C. V., Govender, K., Maredzy, A., Muyanga, S., Farrant, G. M., Thomson, G. I. (2002): Physiological and molecular insight into drought tolerance. - Afr. J. Biotechnol 1: 28-38.

[56] Munns, R. (2002): Comparative physiology of salt and water stress. - Plant Cell Environ. 25: 239-250.

[57] Nad Ali, E. Tadayon, A. S. Tadaayon, M. R. (2014): The effect of salinity on morphological and physiological characteristics of different ecotype fox berry plant germination and growth. - Engineering Journal Desert Ecosystems 2(1): 36-25.

[58] Nedjimi, B., Daoud, Y.(2009): Ameliorative effect of $\mathrm{CaCl} 2$ on growth, membrane permeability and nutrient uptake in Atriplex halimus subsp. schweinfurthii grown at high ( $\mathrm{NaCl})$ salinity. - Desalination 249: 163-166.

[59] Netondo, G. W., Onyango, J. C., Beck, E. (2004): Sorghum and salinity: I. Response of growth, water relation, and ion accumulation to $\mathrm{NaCl}$ salinity. - Crop Science 44: 797805.

[60] Niakan, M., Habibi, A., Goorbanli, M. (2012): Effect of pix on Germination, growth, carbohydrates and antioxidant enzymes in cotton seed. - Iranian Journal of Plant Physiology 1(4): 301-307.

[61] Noor, E., Azhar, F. M., Khan, A. A (2001): Differences in responses of Gossypium hirsutum L. varieties to $\mathrm{NaCl}$ salinity at seedling stage. - Agri. Biol. 3(4).

[62] Oosterhuis, D., Robertson, W. (2000): The use of plant growth regulators and other additives in cotton production. - Proceeding of the 2000 Cotton Research Meeting, Arkansas.

[63] Ozarslan, D. (2002): Physical properties of cotton seed. - Biosystem Engineering 83: 169-174.

[64] Pal, M., Singh, D. K., Rao, L. S., Singh, K. P. (2004): Photosynthetic characteristics and activity of antioxidant enzymes in salinity tolerant and sensitive rice cultivars. - Indian J. Plant Physiol. 9: 407-412.

[65] Parida, A. K., Das, A. B., Mohanty, P. (2004): Defense potentials to $\mathrm{NaCl}$ in a mangrove, Bruguiera parviflora differential changes of isoforms of some antioxidative enzymes. $-\mathrm{J}$. Plant Physiol. 161: 531-542.

[66] Pervaiz, S., Saqib, M., Akhtar, J., Atif Riaz, M., Anwar-ul-Haq, M., Nasim, M. (2007): Comparative growth and leaf ionic composition of four cotton (Gossypium hirsutum L.) genotypes in response to salinity. - Pak. J. Agri. Sci. 44(1): 79-84.

[67] Prado, E. Boero, F.-C., Gallardo, M., Gonzales, J. A. (2000): Effect of salt on germination growth soluble sugar content in Chenpodium Quinoa will. seeds. - Bot. Bull. Acad Sin.41: 27-37.

[68] Renault, S. (2005): Response of red osier dogwood (Cornus stolonifera) seedlings to $\mathrm{Na}^{+}$ sulphate salinity: effects of supplemental calcium. - Pysiological Plantarum 123: 75-81.

[69] Rezaei, M., Khavari Nezhad, R. Fahimi, H. (2005): Cotton plant physiological response to different soil salinity. - Horticultural Research and Builders 17(1): 89-81.

[70] Rhodes, D., Hanson, A. D. (1993): Quaternary ammonium and tertiary sulfonium Compounds in higher-plants. - Annual Review of Plant Physiology and Plant Molecular Biology 44: 357-384.

[71] Rodriguez, A., Rubio, M. (2006): High-affinity potassium and sodium transport systems in plants. - Journal of Experimental Botany 57(5): 1149-1160.

[72] Rontein, D., Basset, G., Hanson, A. D. (2002): Metabolic engineering of osmoprotectant accumulation in plants. - Metab Eng 4: 49-56.

[73] Sairam, R. K., Tyagi, A. (2004): Physiology and molecular biology of salinity stress tolerance in plants. - Curr. Sci. 86: 407-421. 
[74] Saranga, Y., Jiang, C. X., Wright, R. J., Yakir, D., Paterson, A. H. (2004): Genetic dissection of cotton physiological responses to arid conditions and their interrelationships with productivity. - Plant Cell Environ 27: 263-277.

[75] Silberbush, M., Ben-Asher, J. (2001): Simulation study of nutrient uptake by plants from soilless cultures as affected by salinity buildup and transpiration. - Plant Soil 233: 59-69.

[76] Singh, H. (2010): Pix spraying in cotton enhances cutting times, yield and seed vigor. Indian Journal of Agronomy 8: 22-26.

[77] Sosa, L., Llanes, A., Reinoso, H., Reginato, M., Luna,V. (2005): Osmotic and specific ion effect on the germination of Prospisstrombulifera. - Annals of Botany 96: 261-267.

[78] Stewart, A. M. (2005): Suggested guidelines for plant growth regulator use on Louisiana cotton. - Louisiana State Univ. AgCenter Publ. 2918. www.lsuagcenter.com/NR/rdonlyres/8E3A2145-FCFD-43EB-9C3F-

0B7D4F1540E4/12012/pub2918cotton1.pdf (accessed 20 June 2006; verified 27 Aug 2006). Louisiana State Univ., Baton Rouge, LA.

[79] Taiz, L., Zeiger, E. (1998): Plant Physiology. - Sinauer Associates, Inc., Sunderland, MA.

[80] Tamer, H. G., Abdel-al, E.-S.(2012): Phenolic acids and antioxidant properties of barley wholegrine and pearling fractions. - Agricultural and Food Sciences 21(2): 118-131.

[81] Tester, M., Davenport, R. (2003): Na tolerance and Na transport in higher plants. Annals of Botany 91(5): 503-527.

[82] Tuna, A. L., Kaya, C., Ashraf, M., Altunlu, H., Yokas, L., Yagmur, B. (2007): The effects of calcium sulphate on growth, membrane stability and nutrient uptake of tomato plants grown under salt stress. - Environmental and Experimental Botany 59(2): 173-178.

[83] Weibing, X., Rajashekar, C. B. (1999): Alleviation of water stress in beans by exogenous glycine betaine. - Plant Science 148: 185-195.

[84] Weiping, C., Hou, Z., Wu, L., Liang, Y., Wei, C. (2009): Effects of salinity and nitrogen on cotton growth in arid environment. - Plant Soil 326(1-2): 61-73.

[85] Weston, L.A ., C,Bertin and Y.Yang.(2004): Bioactive root exudation in germination species: localization, mode of action and gene regulation.Polish Academy of Sciences Pl.ISSN 0137-5891.

[86] Williams, V., Twine, S. (1960): Flame Photometric Method for Sodium, Potassium and Calcium. - In: Paech, K., Tracey, M. V. (ed.): Modern Methods of Plant Analysis. Vol. V, pp. 3-5. Springer-Verlag, Berlin.

[87] Yang, W. J., Rich, P. J., Axtell, J. D., Wood, K. V., Bonham, C. C., Ejeta, G., Mickelbart, M. V., Rhodes, D. (2003): Genotypic variation for glycinebetaine in sorghum. - Crop Sci. 43: 162-169.

[88] Yokoi, S. (2002): JIRCAS Working Report 25-33 Eucalyptus camaldulensis. - Plant Mol. Biol. 43: 515-25.

[89] Zhang, H. X., Blumwald, E. (2001): Transgenic salt-tolerant tomato plants accumulate salt in foliage but not in fruit. - Nature Biotechnology 19: 765-768.

[90] Zhu, J. K. (2000): Genetic analysis of plant salt tolerance using Arabidopsis. - Plant Physiol. 124: 941-948. 